\title{
David Oliver: The crisis in care home supply
}

\author{
David Oliver consultant in geriatrics and acute general medicine
}

Berkshire

Care homes are a neglected area of public policy that we have to get right. Pressure on care home places is increasing, alongside huge recruitment and funding problems.

Last year Oxford Brookes University's Institute of Public Care (IPC) studied data from the Care Quality Commission and found that, from April 2012 to April 2017, the number of care homes in England fell by 8\%, from 17801 to $16392 .{ }^{1}$

In the UK the term "care home" commonly refers both to residential care homes and nursing homes. While nursing homes employ registered nurses, care homes now increasingly care for older people with highly complex needs and significant physical dependence, disability, or cognitive impairment. ${ }^{23}$ The IPC found that the average size of newly opened care homes ( 37 places) was greater than in those that closed (29), so the overall number of places for older residents increased by $4 \%$, from 387 485 to 404163 . Yet potential demand has outstripped this expansion, as the number of citizens aged over 85 increased by $16 \%$.

Staffing these homes is also a challenge. Skills for Care ${ }^{4}$ has estimated 1.6 million jobs in adult social care, with annual turnover of $30 \%$. Nearly half of these staff work in adult residential and nursing care, with vacancy rates of $11 \% .^{5}$ The workforce is ageing, low paid, and heavily reliant on immigration. ${ }^{4}$ The NHS, and less emotionally demanding and responsible industries, compete with the sector for staff, and recruitment and retention may be further harmed by visa restrictions and the impact of Brexit. Repeated cuts in local government funding (hence adult social care) have made the care home market ever more challenging for operators. ${ }^{67}$ The introduction of the national living wage has created further pressures. $^{8}$

The adult social care workforce is ageing, low paid, and heavily reliant on immigration

I see no meaningful prospect of care homes no longer being required in my lifetime, no matter how much we invest in age friendly housing, prevention, and support at home. Modelling has shown that people living longer will lead to more years spent in high dependence. ${ }^{9}{ }^{10}$ Even health systems lauded for their excellence, person centred processes, and community approaches such as those in the Netherlands and Sweden still have significant per capita places in long term care homes, exceeding those in the UK. ${ }^{11}$

England has serially slashed investment in public health. ${ }^{12}$ We're building too few age friendly homes, ${ }^{13}$ including schemes such as sheltered accommodation or extra care housing for frail or dependent residents. Unpaid, informal family caregivers are already working flat out, at detriment to their own health. The national State of Caring 2018 survey by Carers UK portrayed a grim picture of poor support, inadequate information, and low morale. $^{14}$

With an ageing population and around three times as many people in care homes as in hospitals, ${ }^{15}$ and with many hospital patients unable to access community assessment or rehabilitation after acute illness or injury, ${ }^{16}$ the issue of care homes shouldn't be treated by policy makers as invisible or relegated to the "too difficult” file. It deserves far more prominence and attention.

Competing interests: See www.bmj.com/about-bmj/freelance-contributors/davidoliver

Provenance and peer review: Commissioned; not externally peer reviewed.

1 Institute of Public Care. Market shaping in adult social care. July 2017. http://ipc.brookes ac.uk/publications/Market_Shaping_in_Adult_Social_Care.pdf.

2 British Geriatrics Society. Effective healthcare for older people living in care homes: guidance on commissioning and providing healthcare services across the UK. 2016. https: //www.bgs.org.uk/sites/default/files/content/resources/files/2018-05-10/2016_bgs_ commissioning_guidance.pdf.

3 British Geriatrics Society. How should healthcare services to care homes be configured-results from the Optimal Study. 2 July 2018. https://britishgeriatricssociety. wordpress.com/2018/07/02/how-should-healthcare-services-to-care-homes-be-configuredresults-from-the-optimal-study/\#more-5473.

4 Skills for Care. The state of the adult social care sector and workforce in England. Sept 2018. https://www.skillsforcare.org.uk/NMDS-SC-intelligence/Workforce-intelligence/ documents/State-of-the-adult-social-care-sector/The-state-of-the-adult-social-care-sectorand-workforce-2018.pdf.

5 Age UK. Briefing: health and care of older people in England 2017. Feb 2017. https:// www.ageuk.org.uk/documents/EN-GB/For-professionals/Research/The_Health_and Care_of_Older_People_in_England_2016.pdf?epslanguage=en-GB?dtrk=true.

6 King's Fund. Social care for older people: home truths. 15 Sept 2016. https://www. kingsfund.org.uk/publications/social-care-older-people.

7 Jones R. £1bn funding shortfall may force UK care homes to close, says watchdog. Guardian 30 Nov 2017. https://www.theguardian.com/society/2017/nov/30/funding-shortfalluk-care-homes-close-watchdog.

8 Chandler T. The impact the living wage has on care home providers. Wright Hassall. 23 March 2017. https://www.wrighthassall.co.uk/knowledge/legal-articles/2017/03/23/impactliving-wage-has-care-home-providers. 
9 Kingston A, Wohland P, Wittenberg R, etal. Cognitive Function and Ageing Studies collaboration. Is late-life dependency increasing or not? A comparison of the Cognitive Function and Ageing Studies (CFAS). Lancet 2017;390:1676-84. https://www.thelancet. com/journals/lancet/article/PIIS0140-6736(17)31575-1/fulltext. 10.1016/S0140-6736(17)31575-1 28821408

10 Kingston A, Robinson L, Booth H, Knapp M, Jagger CMODEM project. Projections of multi-morbidity in the older population in England to 2035: estimates from the Population Ageing and Care Simulation (PACSim) model. Age Ageing 2018:47:374-80. https:// academic.oup.com/ageing/article/47/3/374/4815738. 10.1093/ageing/afx201 29370339

11 Robertson R, Gregory S, Jabbal J. The social care and health systems of nine countries. Commission on the Future of Health and Social Care in England; King's Fund. 2014. https://www.kingsfund.org.uk/sites/default/files/media/commission-background-papersocial-care-health-system-other-countries.pdf.
12 Oliver D. David Oliver: Getting serious about prevention. BMJ 2018;360:k583. https:// www.bmj.com/content/360/bmj.k583. 10.1136/bmj.k583 29467152

13 Porteus J, Park J. Age-friendly housing: future design for older people. RIBA Publishing 2018. https://www.ribabookshops.com/item/age-friendly-housing-future-design-for-olderpeople/91915/.

14 Carers UK. State of caring 2018. 10 July 2018. https://www.carersuk.org/for-professionals/ policy/policy-library/state-of-caring-2018-2.

15 British Geriatrics Society. A quest for quality in care homes. 4 March 2012. https://www. bgs.org.uk/blog/a-quest-for-quality-in-care-homes.

16 NHS Benchmarking Network. Work programme report 2016/17. 2017. https://www. nhsbenchmarking.nhs.uk/news/2016-17-round-up-2017-18-news-update?rq=2016\%2F17.

Published by the BMJ Publishing Group Limited. For permission to use (where not already granted under a licence) please go to http://group.bmj.com/group/rights-licensing/ permissions 